\title{
Groundwater Quality in the Mississippi Embayment-Texas Coastal Uplands Aquifer System, South-Central United States
}

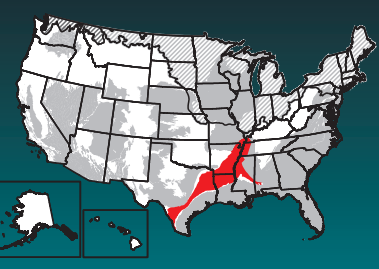

Groundwater provides nearly $\mathbf{5 0}$ percent of the Nation's drinking water. To help protect this vital resource, the U.S. Geological Survey (USGS) National Water-Quality Assessment (NAWQA) Project assesses groundwater quality in aquifers that are important sources of drinking water (Burow and Belitz, 2014). The Mississippi embayment-Texas coastal uplands aquifer system constitutes one of the important aquifer systems being evaluated.

\section{Background}

The Mississippi embayment-Texas coastal uplands aquifer system underlies an area of 117,000 square miles in Texas, Louisiana, Arkansas, Mississippi, Tennessee, Missouri, Kentucky, Illinois, and Alabama. Groundwater is the primary source of drinking water for many of the 7 million people that live in areas overlying this aquifer system. Withdrawals for public and domestic supply from this aquifer system are the 10th largest in the United States, with withdrawals in 2000 of 724 million gallons per day (Mgal/d) for public supply and $100 \mathrm{Mgal} / \mathrm{d}$ for domestic supply (Arnold and others, 2017a; Arnold and others, 2018a). Land use in the area overlying the Mississippi embayment-Texas coastal uplands aquifer system is primarily undeveloped or natural land cover (about 60 percent) and agricultural (34 percent) with a relatively small amount (6.5 percent) of urban and other developed land. Memphis, Tennessee, and Jackson, Mississippi, are the largest metropolitan areas in the study area.

The Mississippi embayment-Texas coastal uplands aquifer system includes formations in the Claiborne and Wilcox Groups that respectively consist of Eocene-age and Eocene- and Paleoceneage sedimentary deposits. As many as five regional aquifers separated in many places by regional confining units make up the aquifer system (Lloyd and Lyke, 1995; Ryder, 1996; Renken, 1998). The middle Claiborne aquifer and the lower Claiborne-upper Wilcox aquifer are present throughout most of the aquifer system and are the primary aquifers used for public supply. These two aquifers were the primary aquifers sampled to characterize groundwater used for public supply in the Mississippi embayment-Texas coastal uplands aquifer system.

Groundwater quality in the Mississippi embayment-Texas coastal uplands aquifer system was evaluated by sampling 89 public-supply wells randomly distributed in an equal area grid. Water-quality data collected from wells in a network designed in this way are representative of the spatial distribution of the water quality in the study area (Belitz and others, 2010). Results from these wells were used to estimate the percentage of the study area with concentrations that are high, moderate, and low with respect to constituent benchmarks. The accuracy of the estimates depends upon the distribution and number of wells, not on the size of the area (Belitz and others, 2010). The wells ranged from about 100 to 4,250 feet (ft) deep with an average depth of about $750 \mathrm{ft}$ and typically had open intervals or screen lengths of between 30 to $100 \mathrm{ft}$. Samples were collected between April and August of 2014 in Arkansas, Kentucky, Louisiana, Mississippi, Missouri, Tennessee, and Alabama and between July and September of 2015 in Texas. The samples were analyzed for a large number of natural and man-made constituents.

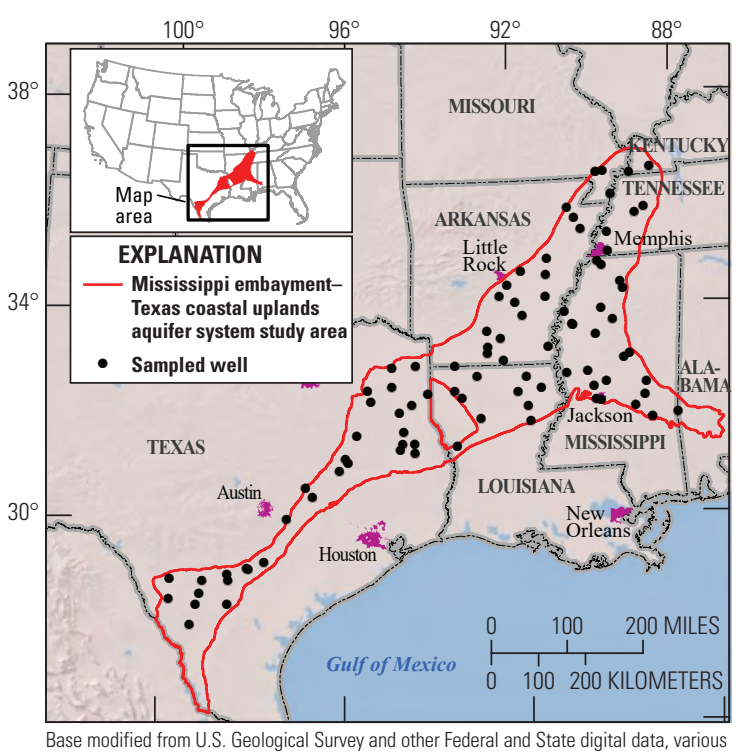

Base modified from U.S. Geological Survey and other Federal and State digital data, various
scales; Albers Equal-Area Conic projection, standard parallels are $29^{\circ} 30^{\prime} \mathrm{N}$. and $45^{\circ} 30^{\prime} \mathrm{N}$; North American Datum of 1983; Shaded relief from ESRI World_Shaded_Relief, 2014

\section{Overview of Water Quality}
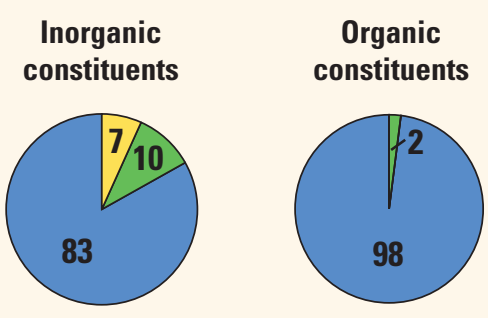

\section{CONSTITUENT CONCENTRATIONS}

High $\bigcirc$ Moderate $\bigcirc$ Low or not detected

Values are a percentage of the study area with concentrations in the three specified categories. Percentages might not sum to 100 because of rounding.

Principal Aquifer Studies are designed to evaluate untreated groundwater used for public supply. Groundwater quality is assessed by comparing concentrations to benchmarks established for drinking-water quality. Benchmarks and definitions of high, moderate, and low relative concentrations are discussed in the inset box on page 3 .

Many inorganic constituents are present naturally in groundwater; however, concentrations can be affected by human activities. One or more inorganic constituents with human-health benchmarks were present at high concentrations in about 7 percent of the study area and at moderate concentrations in about 10 percent.

Man-made organic constituents are found in products used in the home, business, industry, and agriculture. Organic constituents can enter the environment through normal use, spills, or improper disposal; however, they were detected infrequently and typically concentrations were low. One or more organic constituents with human-health benchmarks were detected at moderate concentrations in about 2 percent of the study area. 


\section{Results: Groundwater Quality at the Depth Zone Used for Public Supply in the Mississippi Embayment-Texas Coastal Uplands Aquifers}

\section{INORGANIC CONSTITUENTS}

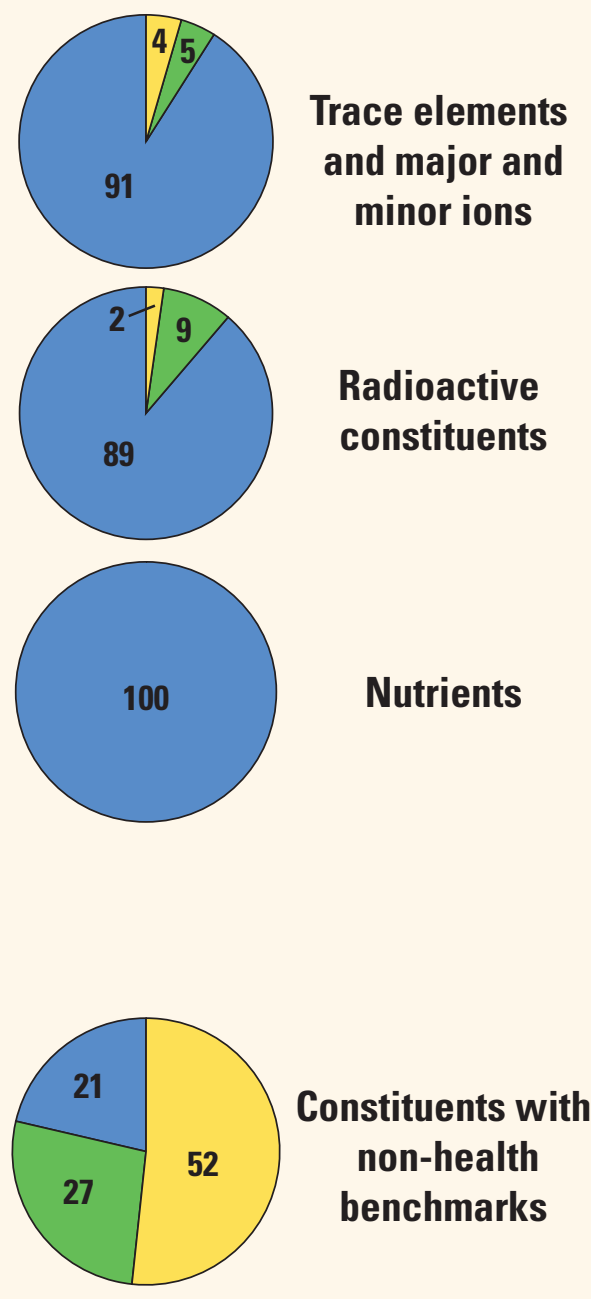

\section{Inorganic Constituents With Human-Health Benchmarks}

Trace elements and major and minor ions are naturally present in the minerals of rocks, soils, and sediments and in the water that comes into contact with those materials. Samples were analyzed for 34 trace elements and major and minor ions, of which 19 have human-health benchmarks. These constituents were detected at high concentrations in about 4 percent of the study area (the depth zone used for public supply) and at moderate concentrations in about 5 percent. Manganese and lead were the only trace elements detected at high concentrations.

Radioactivity is the release of energy or energetic particles during the spontaneous decay of unstable atoms, and humans are continuously exposed to small amounts of natural radioactivity. Most of the radioactivity in groundwater comes from the decay of naturally occurring isotopes of uranium and thorium. Samples were analyzed for eight radioactive constituents, of which four have human-health benchmarks. Radioactive constituents were present at high levels in about 2 percent of the study area and at moderate levels in about 9 percent of the study area. Grossalpha activity and radium were the only radiochemical constituents detected at high concentrations.

Nutrients are naturally present at low concentrations in groundwater; high and moderate concentrations (relative to human-health benchmarks) generally are a result of human activities. Samples were analyzed for five nutrients, of which two (nitrate and nitrite) have human-health benchmarks. Common sources of nutrients, aside from soils, include fertilizer applied to crops and landscaping, seepage from septic systems, and human and animal waste. Nutrients were not present at high or moderate concentrations in the study area.

\section{Inorganic Constituents and Field Measurements With Non-Health Benchmarks}

(Not included in water-quality overview charts shown on the front page)

Some constituents affect the aesthetic properties of water, such as taste, color, and odor, or can create nuisance problems, such as staining and scaling. The benchmarks used for these constituents are non-regulatory secondary maximum contaminant level (SMCL) benchmarks established for public drinking water. Some constituents such as manganese have both humanhealth benchmarks and SMCLs. Samples were analyzed for 11 constituents that have SMCLs. One or more of these constituents were present at high concentrations in about 52 percent of the study area and at moderate concentrations in about 27 percent.

Total dissolved solids (TDS) concentration is a measure of the salinity of the groundwater based primarily on the concentrations of ions, and all water naturally contains TDS because of the weathering and dissolution of minerals in rocks and sediments. Total dissolved solids concentrations can be high as a result of natural factors or human activities such as road salting and some agricultural activities. Total dissolved solids were present at high concentrations relative to the SMCL in about 19 percent of the study area and at moderate concentrations in 29 percent. Chloride was present at moderate concentrations in about 9 percent of the study area. Sulfate was present at high and moderate concentrations in about 1 percent of the study area, and fluoride was present at moderate concentrations relative to the SMCL in about 1 percent of the study area.

Anoxic conditions in groundwater (low concentrations of dissolved oxygen) can result in the release of naturally occurring iron and manganese from minerals into groundwater. Manganese was present at high concentrations relative to the SMCL in about 23 percent of the study area. Iron was present at high concentrations relative to the SMCL in about 30 percent of the study area. Both manganese and iron were present at moderate concentrations in about 10 percent of the study area.

In about 37 percent of the study area, the $\mathrm{pH}$ of groundwater was not in the SMCL range of 6.5 to 8.5 . In about 11 percent of the study area, $\mathrm{pH}$ was lower than 6.5 , which makes the water corrosive, and low $\mathrm{pH}$ can increase concentrations of iron and manganese. In about 26 percent of the study area, $\mathrm{pH}$ was higher than 8.5. High $\mathrm{pH}$ values make the water alkaline, which can affect the taste of water and result in mineral deposits in pipes or plumbing fixtures. 


\section{Results: Groundwater Quality at the Depth Zone Used for Public Supply in the Mississippi Embayment-Texas Coastal Uplands Aquifers}

\section{ORGANIC CONSTITUENTS}

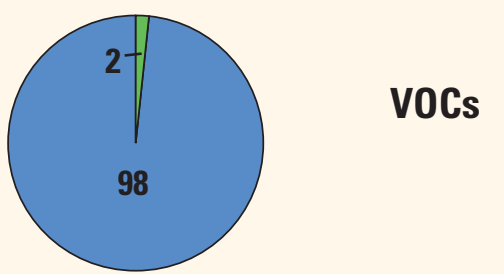

\section{Volatile Organic Compounds With Human-Health Benchmarks}

Volatile organic compounds (VOCs) are present in many household, commercial, industrial, and agricultural products and are characterized by their tendency to volatilize (evaporate) into the air. Samples were analyzed for 90 VOCs, of which 38 have human-health benchmarks. Volatile organic compounds were not detected at high concentrations; however, four compounds were detected at moderate concentrations in 2 percent of the study area. Two of these were trihalomethane compounds (chloroform and dibromochloromethane), and two were solvents (dichloromethane and tetrachloroethylene).

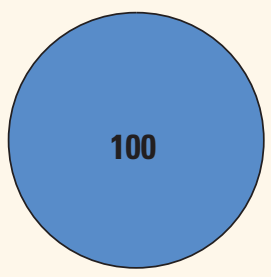

\section{Pesticides With Human-Health Benchmarks}

Pesticides, including herbicides, insecticides, and fumigants, are applied to crops, gardens and lawns, around buildings, and along roads to help control unwanted vegetation (weeds), insects, fungi, and other pests. Samples were analyzed for 227 pesticide compounds (pesticides and their breakdown products), of which 119 have human-health benchmarks. Pesticide compounds were detected in the study area but not at high or moderate concentrations.

\section{BENCHMARKS FOR EVALUATING GROUNDWATER OUALITY}

The USGS NAWQA Project uses benchmarks established for drinking water to provide context for evaluating the quality of untreated groundwater. The quality of water received by customers may be different because after withdrawal, groundwater may be treated prior to delivery. Federal regulatory benchmarks for protecting human health are used for this evaluation of water quality when available. Otherwise, non-regulatory human-health benchmarks and non-regulatory aesthetic benchmarks are used. Not all analyzed constituents have associated benchmarks and thus are not considered in this context. Out of 55 inorganic constituents and properties and 317 organic constituents analyzed, 24 and 157 , respectively, have human-health benchmarks.

Concentrations are considered high if they are greater than a human-health benchmark (Toccalino and others, 2014) or SMCL. For inorganic constituents, concentrations are moderate if they are greater than one-half of a benchmark. For organic constituents, concentrations are moderate if they are greater than one-tenth of a benchmark; this lower threshold was used because organic constituents are generally less prevalent and have smaller concentrations relative to benchmarks than inorganic constituents (Toccalino and others, 2004).

\section{Benchmark Type and Value for Selected Constituents}

This table presents benchmarks for those constituents detected at high concentrations in the Mississippi embayment-Texas coastal uplands aquifer system. Benchmark types are regulatory U.S. Environmental Protection Agency (EPA) maximum contaminant levels (MCLs), non-regulatory health-based screening levels (HBSLs), and non-regulatory EPA secondary maximum contaminant levels (SMCLs).

[Abbreviations: ppb, part per billion (ppb) or microgram per liter $(\mu \mathrm{g} / \mathrm{L}) ; \mathrm{ppm}$, part per million $(\mathrm{ppm})$ or milligram per liter $(\mathrm{mg} / \mathrm{L})$; $\mathrm{pCi} / \mathrm{L}$, picocurie per liter; Ra, radium]

\begin{tabular}{|c|c|c|c|c|}
\hline \multirow{2}{*}{ Constituent } & \multicolumn{2}{|c|}{ Health-based benchmark } & \multirow{2}{*}{ Constituent } & \multirow{2}{*}{$\begin{array}{l}\text { SMCL } \\
\text { Value }\end{array}$} \\
\hline & Type & Value & & \\
\hline Lead & MCL & $15 \mathrm{ppb}$ & Chloride & $250 \mathrm{ppm}$ \\
\hline Manganese & HBSL & $300 \mathrm{ppb}$ & Iron & $300 \mathrm{ppb}$ \\
\hline Gross-alpha activity & MCL & $15 \mathrm{pCi} / \mathrm{L}$ & Manganese & $50 \mathrm{ppb}$ \\
\hline \multirow[t]{3}{*}{ Ra-226+Ra-228 } & MCL & $5 \mathrm{pCi} / \mathrm{L}$ & Sulfate & $250 \mathrm{ppm}$ \\
\hline & & & Total dissolved solids (TDS) & $500 \mathrm{ppm}$ \\
\hline & & & $\mathrm{pH}$ & $6.5-8.5$ \\
\hline
\end{tabular}




\section{Spatial Distribution of Total Dissolved Solids Concentrations}

Inorganic constituents with health-based benchmarks were present at high concentrations in only 6 percent of the study area; however, three constituents (TDS, manganese, and iron) were present at concentrations exceeding non-health benchmarks in about 20 to 30 percent of the study area and at moderate concentrations in about 10 to 30 percent of the study area. In general, iron and manganese concentrations did not have a clear geographic distribution, and moderate to high concentrations were found throughout the study area. In contrast, moderate and high concentrations of TDS were most prevalent in the southern and south-central part of the study area. For example, moderate to high concentrations were found in 78 percent of the samples within Texas. Elevated TDS concentrations in Texas relative to much of the study area may reflect differences in the aquifer composition, lower amounts of recharge, and long groundwater residence times. In the rest of the study area, moderate to high concentrations accounted for about a third of the samples, but high concentrations were found more frequently (16 percent of samples) in Arkansas and Louisiana than in samples collected in Mississippi, Tennessee, Alabama, Missouri, and Kentucky (7 percent). In Louisiana and Arkansas, higher concentrations were most common in the central part of the study area and may reflect long groundwater residence times and, in some cases, the movement of saline water from deep aquifers into the aquifer system (Kingsbury and others, 2014; Stanton and others, 2017).

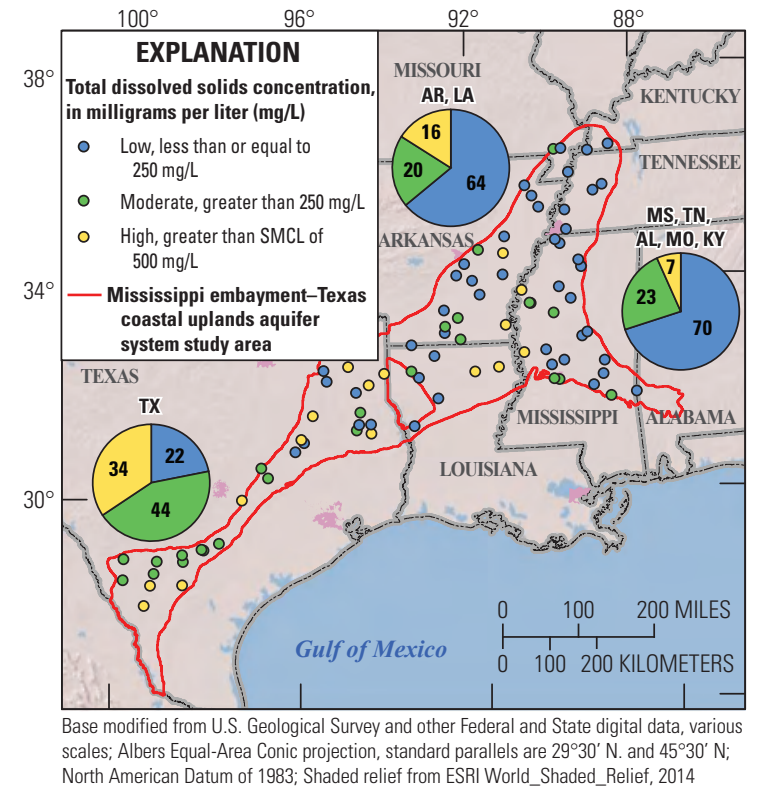

By James A. Kingsbury

\section{Principal Aquifer Surveys}

The USGS NAWQA Project has been assessing the quality of groundwater since 1991. The NAWQA studies include Land Use Studies (LUS), Major Aquifer Studies (MAS), and Principal Aquifer Studies (PAS). These three study types are based on the sampling of networks of wells distributed across an area of interest. The LUS networks typically consist of observation wells that are relatively shallow; MAS networks typically consist of domestic-supply wells that are intermediate in depth; and PAS networks typically consist of public-supply wells that are relatively deep. A national synthesis of shallow and intermediate depth groundwater quality was reported by DeSimone and others (2014). This Fact Sheet provides a summary of PAS data for 89 public-supply wells sampled in 2014 and 2015 in the Mississippi embayment-Texas coastal uplands aquifer system principal aquifer (data available in Arnold and others, 2017b, and Arnold and others, 2018b).

The PAS assessments like this one allow for the comparison of constituent concentrations in untreated groundwater with benchmarks established for the protection of human health and for aesthetic qualities for drinking water and also provide a basis for comparison of groundwater quality among principal aquifers.

The data collected by the NAWQA Project include chemical analyses generally not available as part of regulatory compliance monitoring, including measurements at concentrations much lower than human-health benchmarks and measurement of constituents that can be used to trace the sources and movement of groundwater.

\section{For more information}

Technical reports and hydrologic data collected for the USGS NAWQA Project may be obtained from

\footnotetext{
NAWQA Chief Scientist

U.S. Geological Survey

12201 Sunrise Valley Drive, MS 413

Reston, VA 20192-0002

Email: nawqapublicinfo@usgs.gov

WEB: https://water.usgs.gov/nawqa/
}

J.K., 2017, Brackish groundwater in the United States: U.S. Geological Survey Professional Paper 1833, 185 p., https://doi.org/10.3133/pp1833.

Toccalino, P.L., Norman, J.E., Phillips, R.H., Kauffman, L.J., Stackelberg, P.E., Nowell, L.H., Krietzman, S.J., and Post, G.B., 2004, Application of healthbased screening levels to ground-water quality data in a state-scale pilot effort: U.S. Geological Survey Scientific Investigations Report 2004-5174, $64 \mathrm{p}$.

Toccalino, P.L., Norman, J.E., and Schoephoester, K.M., 2014, Health-based screening levels for evaluating water-quality data: U.S. Geological Survey National Water-Quality Assessment Program web page, doi:10.5066/F71C1TWP, accessed at https://water.usgs.gov/nawqa/HBSL.
ISSN 2327-6916 (print) ISSN 2327-6932 (online)

https://doi.org/10.3133/fs20183067 